\title{
The Influence of Psycho Emotional State of the Cardio-Vascular Disease Patient to the CHD Treatment Outcome
}

\author{
Raushania Gaufullina ${ }^{1}$, Farida Rizvanova ${ }^{2}$, Farida Ishkineeva ${ }^{1}$, Elvira Khusnullina ${ }^{1} \&$ Zulfia Kim $^{2,3}$ \\ ${ }^{1}$ Kazan Federal University, Kazan, Russia \\ ${ }^{2}$ Kazan State Medical University, Kazan, Russia \\ ${ }^{3}$ Emergency care hospital \#1, Kazan, Russia \\ Correspondance: Raushania Gaifullina, Institute of Fundamental Medicine and Biology, Kazan, 420008, \\ Republic of Tatarstan, Russian Federation. Tel: 7-843-233-7841. E-mail: raushania13@rambler.ru
}

Received: September 20, 2014

Accepted: September 29, $2014 \quad$ Online Published: December 17, 2014

doi:10.5539/mas.v9n1p178

URL: http://dx.doi.org/10.5539/mas.v9n1p178

\begin{abstract}
Psycho emotional state of coronary heart disease (CHD) patients and its influence on CHD treatment outcome has been studied according to CES-D and HADS(D) questionnaires. It was demonstrated that the use of agomelatine leads to the decrease of anxiety and depression evidence.
\end{abstract}

Keywords: coronary heart disease, anxiety, depression, agomelatine

\section{Introduction}

Cardiovascular disease is the first reason in the list of overall mortality of Russian population. Cardiovascular disease is the reason of the death of 1,3 million of Russians which is about $56 \%$ of the number of registered deaths. High spread and juvenation of CHD is strongly connected with the increase of psycho-emotional trouble in society. Periods of socio-economical crisis are accompanied with emotional stress and depressive disorders, and consequently, reduce of the life time, increase of the fatality and sickness rates.

The recent researches give the evidence that depression becomes an independent risk factor of arterial hypertension (AH) and $\mathrm{CHD}$, as well as more serious epiphenomenon such as acute myocardial infarction (MI) and cerebral stroke. Depression complicates clinical progression, treatment and

secondary prevention, it also worsen the life quality of patients. The risk of CHD is higher among those who are suffering from depression, and vise versa depression is more often diagnosed at CHD patients (Bromet, 2011, Kopina, 1996, Barefoot, 1996, Wulsin, 1999, Anda, 1993). The degree of depression incidence can reach up to $20 \%$ among CHD patients, and it can be up to $30 \%$ among patients underwent MI (Pogosova, 2002). The risk of rehospitalization and fatal outcome is higher in case of the CHD and depression combination regardless of which of these sicknesses appeared first.

One of the perspective instruments of the pharmacological correction of the depression, which is actually a new approach to its treatment, is the first melatonergic antidepressant agomelatine "Valdoxan" produced by the French pharmaceutical company Servier. This is the medicinal remedy with innovational characteristics. The unique profile of the receptor binding of agomelatine explains its strong antidepressant effect and complementary clinical attribute. The medical remedy normalizes circadian rhythms, restore a good sleep, it is neutral towards the body mass, and it hasn't negative effect towards the genital sphere. Complying antidepressive impact of the medicament, these qualities help to improve compliance and increase therapeutic effect of agomelatine.

Psycho emotional state of the CHD patients and the influence of melatonergic antidepressant agomelatine (Valdoxan) on it were studied during the research.

The research was organized in two stages, as follows: firstly, piloting stage was dedicated to the evaluation of the psycho emotional state of patients who were hospitalized to the acute cardiology unit of the Kazan Emergency care hospital \#1; the first group was presented with patients hospitalized to the reanimation and intensive care ward with 20 people ( 7 men and 13 women at the age of $43-79$ years, in average 64,33 $\pm 1,57$ years). There were 13 people with acute myocardial infarction, 4 with effort angia of III-IV function classes, 2 with atrial fibrillation. 
The second group was presented with 20 people ( 8 men and 12 women at the age of 49-84 years, in average $63,4 \pm 1,34$ years) whose condition didn’t demand the reanimation and intensive care ward. Acute myocardial infarction was diagnosed at 4 patients, effort angia of III-IV function classes at 14 patients, atrial fibrillation at 8 patients. All the patients filled 2 questionnaires, as follows: Center for Epidemiological Studies Depression Scale (CES-D) and Hospital Anxiety and Depression Scale (HADS(D)) at the $2^{\text {nd }}, 6^{\text {th }}$, and $10-14^{\text {th }}$ days at hospital.

At the second stage the influence of Valdoxan on the clinical and subclinical depression and axiety progress was studied at 38 CHD patients at the age of $43-79$ years ( 10 men and 28 women, average age is $66,44 \pm 3,39$ years). There were 27 patients with acute myocardial infarction (among them 8 with repeated), 9 with effort angia of III-IV function classes, 9 with atrial fibrillation; 21 patients of this group suffered from hypertensive disease, and 3 had symptoms of cardiac asthma. It bears mentioning, that 4 patients were brought to the hospital with cardiogenic shock of the I-II degree, and 4 - with pulmonary edema. Conduction defects with block of the left or right His bundle branch were diagnosed at 4 patients, and rhythm disturbance in pair multifocal multiform infranodal and auricular extrasystoles were diagnosed at 2 patients. Aiming to correct depression and anxiety order these patients were ordered to take antidepressant agomelatine (Valdoxan) - melatonin agonist $\left(\mathrm{MT}_{1}\right.$ - and $\mathrm{MT}_{2}$-receptors) and $5 \mathrm{HT}_{2 \mathrm{c}}$-receptors agonist in a dose of $25 \mathrm{mg}$ every evening.

All patients were surveyed according to the CES-D depression scale and HADS (D, T) scale in terms of determination of their psycho emotional state at the $2^{\text {nd }}, 6^{\text {th }}$ and $14^{\text {th }}$ day at the hospital. The outcome was interpreted as follows: remarkable depression or anxiety $->25$ points according to the CES-D scale and 11 points according to the HADS (D, T) scale; subclinical remarkable anxiety/depression - 19-25 or 8-10 points; the absence of definitively remarkable symptoms of anxiety/depression 0-19 or 0-7 points.

Statistic material handling was organized with the use of standard program package Statistica.

Regarding the first group $(\mathrm{n}=20)$ of patients who were at the reanimation and intensive care ward, $15(75 \%)$ of patients were diagnosed with depression at the second day. Among them 5(25\%) patients were diagnosed with remarkable depression according to the CES-D scale, $10(50 \%)$ with light, and 5(25\%) -without pathological findings. There were 19 (95\%) of patients who were diagnosed with depression according to the HADS(D) scale, among them 15(75\%) - clinically apparent, 4(20\%) - subclinical and 1(5\%) - wasn't diagnosed with depression. Expressed depression according to the CES-D scale remained at 1(5\%) patient and at 7(35\%) - light depression at the $14^{\text {th }}$ day. Clinically apparent depression remained at $6(30 \%)$ patients and subclinical at $7(35 \%)$ according to the HADS(D) scale.

Regarding the second group $(\mathrm{n}=20)$ of patients, $6(30 \%)$ of patients were diagnosed with depression at the second day according to the CES-D scale, and among them $2(10 \%)$ patients were diagnosed with remarkable depression, $4(20 \%)$ - light depression; 14(70\%) didn't have psychiatric disorder. However, according to the HADS(D) scale 16 (80\%) patients were diagnosed with depression, among them 7(35\%) - clinically apparent, $9(45 \%)$ - subclinical, and 4(20\%) - no depression. There were only 3(15\%) patients with light depression according to the CES-D scale; and 3(15\%) - clinically apparent, $4(20 \%)$ subclinical according to the HADS(D) scale on the $14^{\text {th }}$ day.

Summarized data about the depression levels according to the CES-D scale at the $2^{\text {nd }}$ and $14^{\text {th }}$ days is presented at the Figures 1, 2. According to the HADS(D) scale, depression was diagnosed at 35(87,5\%) patients, among them: $22(55 \%)$-remarkable depression, $13(32,5 \%)$ - subclinical, and $5(12,5 \%)$ - no depression; at the $14^{\text {th }}$ day there were $9(25,7 \%)$ of 35 patients with clinically apparent depression, and $11(31,43 \%)$ with subclinical. 


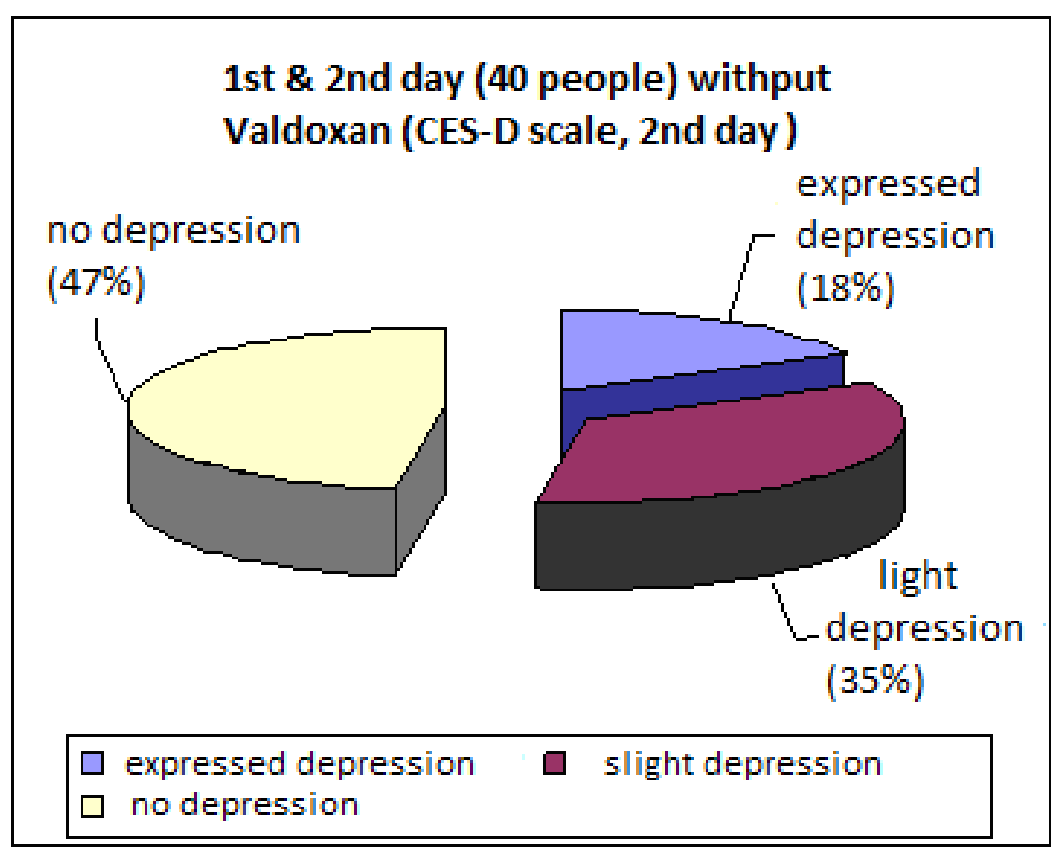

Figure 1. Psycho emotional state of the patients of the first two groups at the $2^{\text {nd }}$ day in hospital (CES-D)

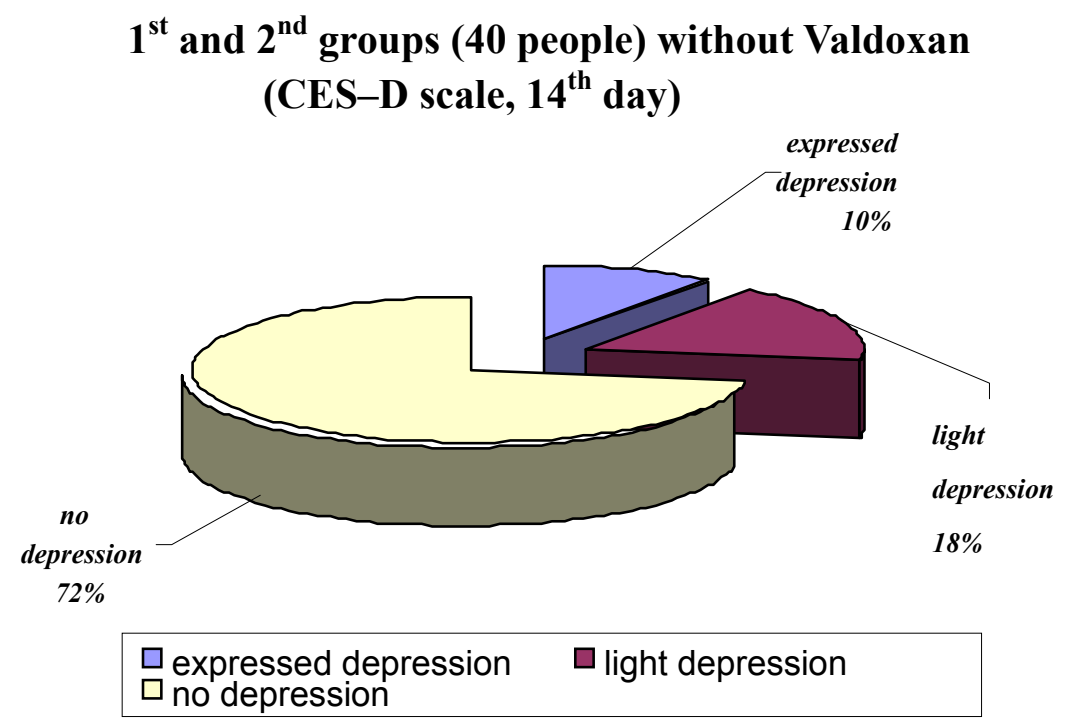

Figure 2. Psycho emotional state of the patients of the first two groups at the14th day in hospital (CES-D) 


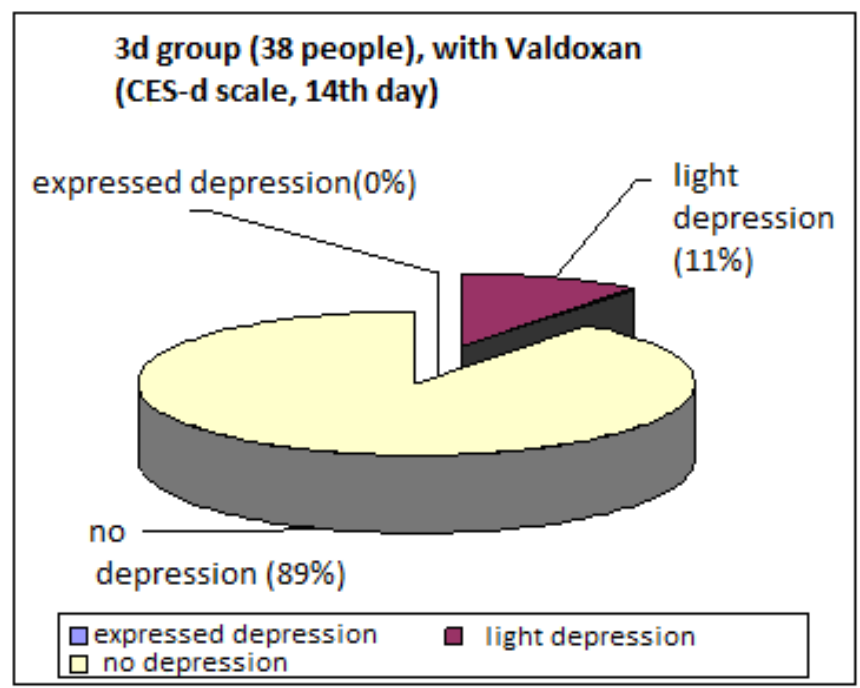

Figure 3. Psycho emotional state of the patients of Valdoxan group at the $2^{\text {nd }}$ day in hospital (CES-D)

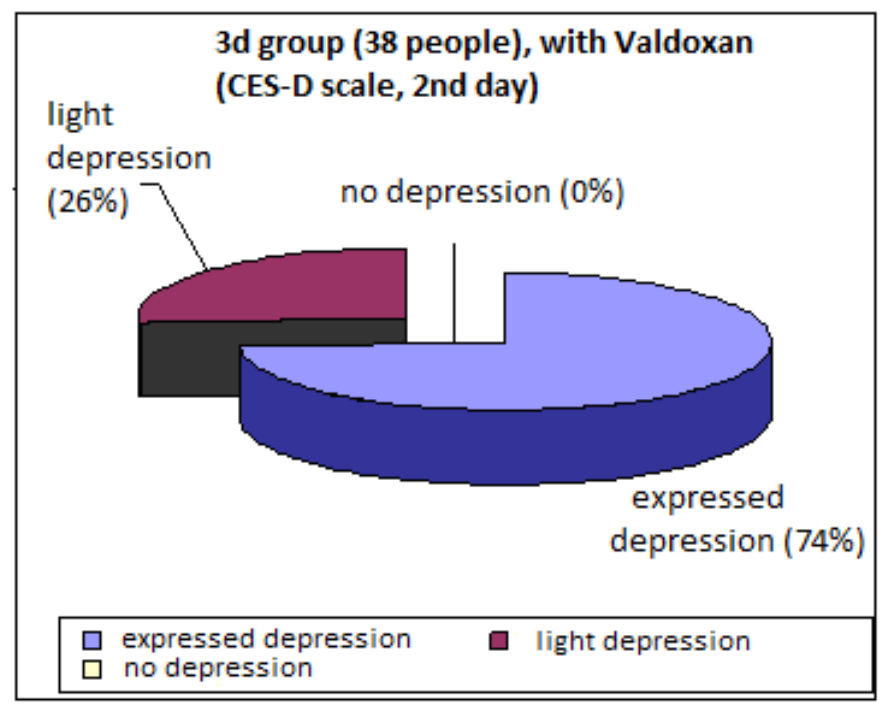

Figure 4. Psycho emotional state of the patients of Valdoxan group at the $14^{\text {na }}$ day in hospital (CES-D)

The level of the depression according to the CES-D scale of 38 patients taking Valdoxan at the second day is presented at the Figure 3. According to the HADS(D) scale anxiety at the $2^{\text {nd }}$ day was revealed at 29 patients, among them 16(42,1\%) - subclinical depression, and $13(34,2 \%)$ - clinically apparent depression, $9(23,7 \%)-$ without pathology. At that time, there were $19(50 \%)$ of depressed people, among them $12(31,6 \%)$ - subclinical depression, $7(18,45 \%)$ - clinically apparent depression, and $19(50 \%)$ - without significant depression. There were $5(13,15 \%)$ people with light depression and $13(34,2 \%)$ with remarkable depression at the $6^{\text {th }}$ day according to the CES-D scale. According to the HADS(D) scale, there were $6(15,8 \%)$ patients with clinically apparent depression and $4(10,5 \%)$ - with light depression. According to the HADS(D) scale, anxiety disorder was noted at 11 people, among them $6(15,7 \%)$ - in subclinical form, and $5(13,1 \%)$ - in clinically apparent form. At the time of hospital discharge $\left(10^{\text {th }}-14^{\text {th }}\right.$ day), there were only 3 patients with light depression(initially 38 patients had clinically apparent depression); their anxiety level has reduced (Figure 4), so they were proposed to continue outpatient use of Valdoxan.

Subjective feelings, as mood, sleep, psycho-emotional state, improved already on the $2-4^{\text {th }}$ days of the medication use. Above that, Valdoxan demonstrated metabolical neutrality, which extends the opportunities of its use for the different groups of patients. Functional tests which were organized during 14 days of attendance haven't significantly changed, alanine/aspartate transaminase content was in average $38,08 \pm 1,34 / 28,6 \pm 2,32$ и $39,26 \pm 1,65 / 30,1 \pm 2,53 \mathrm{u} / 1$ at the $2^{\text {nd }}$ and $14^{\text {th }}$ days accordingly. 
Some of the demographical, social, anamnestic, clinical and haemodynamic characteristics are presented in the table.

Table 1. Clinical-anamnestic characteristics of the patients

\begin{tabular}{|c|c|c|c|}
\hline Parameter & $\begin{array}{l}1^{\text {st }} \text { group (the } \\
\text { reanimation and intensive } \\
\text { care ward, without } \\
\text { Valdoxan, } n=20)\end{array}$ & $\begin{array}{lr}2^{\text {nd }} & \text { group } \\
\text { (medical unit, } & \text { without } \\
\text { Valdoxan, } n=20 \text { ) } & \end{array}$ & $\begin{array}{l}3^{\text {rd }} \text { group (with } \\
\text { depression, with Valdoxan, } \\
\mathbf{n = 2 0 )}\end{array}$ \\
\hline Age, years & $64,33 \pm 1,57$ & $63,4 \pm 1,34$ & $66,44 \pm 3,39$ \\
\hline Men, absolute data (\%) & $7(35)$ & $8(40)$ & $10(26,3)$ \\
\hline Women, absolute data (\%) & $13(65)$ & $12(60)$ & $28(73,7)$ \\
\hline Married, absolute data (\%) & $5(25)$ & $7(35)$ & $12(31,6)$ \\
\hline Single, absolute data (\%) & $6(35)$ & $3(15)$ & $4(10,5)$ \\
\hline Widow, absolute data (\%) & $1(5)$ & $5(25)$ & $20(52,6)$ \\
\hline Divorced, absolute data (\%) & $8(40)$ & $5(25)$ & $2(5,3)$ \\
\hline $\begin{array}{l}\text { Duration of a heart disease } \\
\text { (CHD) }\end{array}$ & $18,3 \pm 2,21$ & $11,5 \pm 6,42$ & $12,1 \pm 4,86$ \\
\hline $\begin{array}{l}\text { Myocardial infarct, absolute } \\
\text { data (\%) }\end{array}$ & $13(65)$ & $4(20)$ & $27(71)$ \\
\hline $\begin{array}{l}\text { Effort angia of III-IV function } \\
\text { classes absolute data }(\%)\end{array}$ & $3(15)$ & $14(70)$ & $17(44,7)$ \\
\hline $\begin{array}{l}\text { Postinfarction cardiosclerosis, } \\
\text { absolute data }(\%)\end{array}$ & $0(0)$ & $8(40)$ & $0(0)$ \\
\hline $\begin{array}{l}\text { Atrial fibrillation/ ventricular } \\
\text { arrhythmia rhythm } \\
\text { disturbance, absolute data (\%) }\end{array}$ & $\begin{array}{l}2(10) / \\
0(0)\end{array}$ & $\begin{array}{l}2(10) / \\
0(0)\end{array}$ & $\begin{array}{l}9(23,7) / \\
2(5,3)\end{array}$ \\
\hline $\begin{array}{l}\text { Cardiac conduction defect, } \\
\text { absolute data }(\%)\end{array}$ & $0(0)$ & $4(20)$ & $4(10,5)$ \\
\hline $\begin{array}{l}\text { Patients with arterial } \\
\text { hypertension, absolute data } \\
(\%)\end{array}$ & $13(65)$ & $14(70 \%)$ & $21(55,3)$ \\
\hline $\begin{array}{l}\text { Patients without arterial } \\
\text { hypertension, absolute data } \\
(\%)\end{array}$ & $7(35)$ & $6(30)$ & $17(44,7)$ \\
\hline $\begin{array}{l}\text { Cardiogenic shock, absolute } \\
\text { data }(\%)\end{array}$ & $3(15)$ & $0(0)$ & $4(10,5)$ \\
\hline $\begin{array}{l}\text { Pulmonary edema / cardiac } \\
\text { asthma, absolute data (\%) }\end{array}$ & $2(10)$ & $0(0)$ & $\begin{array}{l}4(10,5) \\
3(7,8)\end{array}$ \\
\hline Diabetes, absolute data (\%) & $5(25)$ & $3(15)$ & $4(10,5)$ \\
\hline $\begin{array}{l}\text { Arthrosis, arthritis, absolute } \\
\text { data }(\%)\end{array}$ & $3(15)$ & $2(10)$ & $3(7,8)$ \\
\hline $\begin{array}{l}\text { Digestive tract sickness, } \\
\text { absolute data }(\%)\end{array}$ & $0(0)$ & $0(0)$ & $6(15,7)$ \\
\hline $\begin{array}{l}\text { Kidney Disease (kidney stone } \\
\text { disease, pyelonephritis), } \\
\text { absolute data (\%) }\end{array}$ & $4(20)$ & $5(0)$ & $4(10,5)$ \\
\hline 6-minutes walk test, $\mathrm{m}$ & $303 \pm 4,43$ & $320 \pm 3,33$ & $318 \pm 8,55$ \\
\hline $\begin{array}{l}\text { Systolic blood pressure, } \mathrm{mm} \\
\mathrm{Hg}\end{array}$ & $159,8 \pm 4,12$ & $143,5 \pm 6,32$ & $137,3 \pm 9,15$ \\
\hline Diastolic blood pressure, $\mathrm{mm}$ & $93,5 \pm 7,25$ & $78,5 \pm 2,15$ & $89,5 \pm 6,15$ \\
\hline
\end{tabular}


$\mathrm{Hg}$

Heart rate, per minute

$83,2 \pm 3,45$

$90,1 \pm 4,53$

$96,04 \pm 7,85$

Among the patients hospitalized to the acute cardiology unit more that $1 / 2(52,5-82,5 \%$ according to the evaluation methods) suffer from anxiety/depression disorder, it is worth mentioning that psycho-emotional disorder can be found more often at women over 60 years with more serious cardio-vascular anamnesis, as follows: the first or repeated acute myocardial infarct, with arterial hypertension of II-III degree. It is notable that social state also has a significant effect, so people underwent spouse lost (widows) are more liable to significant anxiety/depressive disorders.

It bears mentioning that being in reanimation and intensive care ward correlates with worse psycho emotional state of CHD sickness. High anxiety or depression level at these patients can become the reason of the secondary disorder connected to the severity of illness and/or condition, to the fact of the serious diagnosis was established, or to being in reanimation and intensive care ward. So, the level of the depression at significant majority of patients has significantly reduced after shifting to the general medical unit.

Anxiety-depressive disorder at the CHD patients regress together with the main treatment, so it is as follows: from 52,5 to $27,5 \%$ (CES scale) and from 82,5 to $58 \%$ (HADS scale) at the $6^{\text {th }}$ day in the hospital. It may be due to reduce of the symptoms marks and the enlargement of physical activity. The use of Valdoxan optimize the psycho emotional state of the ptients, so the frequency of anxiety disorders to the $14^{\text {th }}$ day of the treatment reduced from 76,9 to 2,63\%, depressions - from 50 to 7,89\% (and all the remained cases are of light depression).

The including of new antidepressant Valdoxan to the complex therapy of CHD patients suffering from depression in the dose of $25 \mathrm{mg}$ per day can significantly improve the life quality of patients, which is finally effects the stabilization of the main sickness and improves the life perspectives. Metabolical neutrality of the medicament let recommend it to the patients of different groups, and 1 pill for the night encourage high medication adherence.

To sum up, taking into account possible worsen of the progress and perspective of CHD together with psycho emotional state disorder, we recommend to survey cardiology patients according to CES-D and HADS(D) methodology and in case of anxiety or depression treat them with the use of Valdoxan.

\section{Acknowledgements}

This work was funded by the subsidy allocated o Kazan Federal University for the state assignment in the sphere of scientific activities.

\section{References}

Anda, R., Williamson, D., \& Jones, D. et al. (1993). Depressed affect, hopelessness, and the risk of ischemic heart disease in a cohort of U.S. adults. Epidemiology, 4, 285-294. http://dx.doi.org/10.1097/00001648-199307000-00003

Barefoot, J., \& Scholl, M. (1996). Symptoms of depression, acute myocardial infarction, and total mortality in a community sample. Circulation, 93, 1976-1980. http://dx.doi.org/10.1161/01.CIR.93.11.1976

Bromet, E., Andrade, L., \& Hwang, I. et al. (2011). Cross-National Epidemiology of DSM-IV Major Depressive Episode. BMC Medicine. http://dx.doi.org/10.1186/1741-7015-9-90

Kopina, O., Suslova, S., \& Zaikin, E. (1996). Population study of psycho-emotional stress as cardio-vascular disease risk factor. Cardiology, 36(3), 53-56.

Pogosova, V. (2002). Depression at patients with ischemic heart disease and new ways of its treatment. Consilium Medicum (Addition. Psychiatrics and psychopharmacotherapy), 4(5).

Wulsin, L., Vaillant, G., \& Wells, V. (1999). A systematic review of the mortality of depression. Psychosom. Med., 61, 6-17. http://dx.doi.org/10.1097/00006842-199901000-00003

\section{Copyrights}

Copyright for this article is retained by the author(s), with first publication rights granted to the journal.

This is an open-access article distributed under the terms and conditions of the Creative Commons Attribution license (http://creativecommons.org/licenses/by/3.0/). 